\title{
INFLUENCE OF IRRIGATION AND PLACEMENT OF NITROGEN FERTILIZERS ON THE UPTAKE OF NITROGEN BY SPRING WHEAT
}

\author{
Armi Kaila and PaAvo Elonen \\ University of Helsinki, Department of Agricultural Chemistry
}

Received December 18, 1969

Field experiments on arable crops seldom account for more than one half of the nitrogen applied in fertilizers (Russell 1961, Cooke 1964, KaIla 1965 etc.). This may be attributed to leaching or denitrification, to volatilization or immobilization. In any case, a large part of the expensive fertilizer nitrogen is likely to be wasted.

Lack of movement into the root zone of even nitrates applied as surface dressing to spring cereals was demonstrated in Finnish field experiments, and placement or working in of nitrogen fertilizers was recommended (KaILA and HänNINEN 1961). Because of the usual dry period in the beginning of the summer in Finland, attention has also been paid to the possibilities of improving the efficiency of nitrogen fertilizers by irrigation (ELONEN et. al, 1967).

In the present paper results are reported from a field experiment which was conducted to study the influence of sprinkler irrigation, and the placement and chemical composition of the nitrogen fertilizer on the uptake of nitrogen by spring wheat.

\section{Experimental}

In 1969 a large field trial was carried out in southern Finland, in the neighbourhood of Helsinki, in cooperation with the Finnish Research Institute of Agricultural Engineering. Sprinkler irrigation was studied at four rates, and three kinds of nitrogen fertilizers were either placed or applied as a surface dressing. The uptake of nitrogen by spring wheat was followed by collecting samples of the aerial parts during the growing period.

The soil was silty clay with an average clay content of 50 per cent. The $\mathrm{pH}$ of the ploughing layer was about 6 (in $0.01 \mathrm{M} \mathrm{CaCl}_{2}$ ), and the content of organic $\mathrm{C}$ was 4-5.5 per cent.

The nitrogen fertilizers studied were a Finnish ammonium nitrate-limestone, „Oulun- 
salpietari», urea and an American preparate of Ureaform contributed by Typpi Oy. They were applied just before sowing with a "Juko"-fertilizer drill in amounts corresponding to $120 \pm 1 \mathrm{~kg} \mathrm{~N} / \mathrm{ha}$, either on the surface with the plastic fertilizer tubes outdrawn from the coulters, or at the depth of $8 \mathrm{~cm}$ with a spacing of $15 \mathrm{~cm}$ between the rows.

The plots studied in the present work were irrigated with slow sprinklers in the night June 9 and June 17, at both times with $30 \mathrm{~mm}$ of drainage ditch water, and compared with plots without irrigation.

As a basal dressing $800 \mathrm{~kg} / \mathrm{ha}$ of an ammoniated Finnish PK fertilizer was placed at the depth of $7 \mathrm{~cm}$ with the "Juko"-fertilizer drill at right angles to the seed rows. Thus, $16 \mathrm{~kg} \mathrm{~N}, 60 \mathrm{~kg} \mathrm{P}$ and $100 \mathrm{~kg} \mathrm{~K}$ were applied per hectare.

All treatments were in four replicates. The total area of a plot was $2 \times 24 \mathrm{~m}^{2}$, that of the plot harvested was $1.68 \times 16 \mathrm{~m}^{2}$.

On May 8, "Ruso»-spring wheat was sown with row spacings of $12 \mathrm{~cm}$ at the depth of $4.5 \mathrm{~cm}$. The sprouting date was May 20, that of coming to ear July 2. The yield was harvested on August 20.

The growing season was very dry. The precipitation was $37 \mathrm{~mm}$ in May, $22 \mathrm{~mm}$ in June, $55 \mathrm{~mm}$ in July, and in August from the 1st to the 20th there was no rain. The mean temperatures did not markedly differ from those of a normal season.

Plant samples were collected from each four replicate plots of the treatments studied by cutting the aerial parts from carefully measured strips at the end of the plots. The sampling area was $1.68 \mathrm{~m}^{2}$ on June $2,0.84 \mathrm{~m}^{2}$ on June $16,0.50 \mathrm{~m}^{2}$ on June 30 , and $0.42 \mathrm{~m}^{2}$ on both July 21 and August 18. The ears were cut from the samples of July and August and analysed separately from the leaves and straw. The samples were air-dried at room temperature and ground in a Wiley mill. Total nitrogen was determined with the common Kjeldahl procedure.

The results reported of the grain yields represent winnowed material.

The statistical treatment of the data was performed by the new multiple range test of Duncan (1955).

\section{Results}

The nitrogen content of the aerial parts of wheat plants collected in June are reported in Table 1. Since the common Kjeldahl procedure was used, it is likely that nitrate, if present, was not totally included. The treatment »Without $\mathrm{N}$ » did not get the additional application of $120 \mathrm{~kg} / \mathrm{ha}$ of nitrogen, only the $16 \mathrm{~kg} / \mathrm{ha}$ in the basal dressing.

On June 2, or about two weeks after sprouting, the beneficial effect of the placement of the nitrogen fertilizers is distinct. As a surface dressing, only ammonium nitrate-limestone has produced plant material with a higher nitrogen content than that without the additional nitrogen fertilization. Later, even surface-applied urea did increase the nitrogen content, but in each case, the placement significantly improved this effect. On the other hand, placement of ammonium nitrate-limestone did not increase the effect on the irrigated plots.

On June 16, or about one week after the first irrigation, and on June 30, or about two weeks since the second irrigation, the nitrogen content of the irrigated plants was in most cases significantly higher than that of the unirrigated ones. This was the case even when no additional nitrogen was applied. 
Table 1. $\mathrm{N}$ in shoots, per cent of dry matter

\begin{tabular}{|c|c|c|c|c|c|c|}
\hline \multirow{2}{*}{\multicolumn{2}{|c|}{ Irrigation $\mathrm{mm}$}} & \multirow{2}{*}{$\begin{array}{c}\text { June } 2 \\
0\end{array}$} & \multicolumn{2}{|c|}{ June 16} & \multicolumn{2}{|c|}{ June 30} \\
\hline & & & 0 & 30 & 0 & $30+30$ \\
\hline Without $\mathrm{N}$ & & $4.49^{\mathrm{a}}$ & $2.71^{\mathrm{a}}$ & $3.01^{\mathrm{bc}}$ & $1.53^{\mathrm{a}}$ & $1.68^{\mathrm{bcd}}$ \\
\hline \multicolumn{7}{|c|}{ Ammonium nitrate-limestone } \\
\hline & surface & $4.92^{\mathrm{b}}$ & $3.27^{\mathrm{cd}}$ & $4.12^{\mathrm{efg}}$ & $1.85^{\mathrm{cd}}$ & $2.42^{\mathrm{fg}}$ \\
\hline & placement & $5.26^{\mathrm{c}}$ & $3.86^{\mathrm{ef}}$ & $4.32 \mathrm{~g}$ & $2.08^{\mathrm{e}}$ & $2.41^{\mathrm{fg}}$ \\
\hline \multicolumn{7}{|l|}{ Urea } \\
\hline & surface & $4.57^{\mathrm{ab}}$ & $3.16^{\text {bcd }}$ & $3.82^{e}$ & $1.87^{\mathrm{d}}$ & $2.25^{\mathrm{ef}}$ \\
\hline & placement & $5.22^{\mathrm{c}}$ & $3.86^{\mathrm{ef}}$ & $4.17^{\mathrm{fg}}$ & $2.09^{\mathrm{e}}$ & $2.58 \mathrm{~g}$ \\
\hline \multicolumn{7}{|l|}{ Ureaform } \\
\hline & surface & $4.46^{\mathrm{a}}$ & $2.84^{\mathrm{ab}}$ & $3.27 \mathrm{~cd}$ & $1.66^{\mathrm{bc}}$ & $1.86^{\mathrm{cd}}$ \\
\hline & placement & $4.86^{\mathrm{b}}$ & $2.90^{\mathrm{b}}$ & $3.45^{\mathrm{d}}$ & $1.68^{\mathrm{bcd}}$ & $1.89^{\mathrm{d}}$ \\
\hline
\end{tabular}

Means for samples of the same date followed by a common letter do not differ at $\mathrm{P}=0.05$.

There was in no case any significant difference in the nitrogen content of plants treated in the same way either with urea or with ammonium nitrate-limestone. Ureaform could not compete with them.

The nitrogen content of the plants at later stages of development is reported in Table 2. "Straw» stands for the vegetative aerial parts. In the samples of July 21, no positive effect of irrigation on the nitrogen content can be found: the corresponding values either do not differ from each other, or the plant material from the irrigated plots is poorer in nitrogen than that from the respective unirrigated plots, as is the case with the ears from the plots surface-dressed with ammonium nitrate-limestone. In the samples collected just before harvest, or on August 18, this tendency of irrigation to lower the nitrogen content of the ears is distinct, particularly, when additional nitrogen was

Table 2. $\mathrm{N}$ in straw and ears, per cent of dry matter

\begin{tabular}{|c|c|c|c|c|c|c|c|c|}
\hline & Irrigation & \multirow[t]{2}{*}{ Without N } & \multicolumn{2}{|c|}{$\begin{array}{l}\text { Ammonium nitrate- } \\
\text { limestone }\end{array}$} & \multicolumn{2}{|c|}{ Urea } & \multicolumn{2}{|c|}{ Ureaform } \\
\hline & $\mathrm{mm}$ & & surface & placement & surface & placement & surface & placement \\
\hline \multicolumn{9}{|l|}{ July 21} \\
\hline \multirow[t]{2}{*}{ Straw } & 0 & $0.85^{\mathrm{a}}$ & $1.34^{\mathrm{cd}}$ & $1.52^{\mathrm{ef}}$ & $1.31^{\mathrm{c}}$ & $1.60^{f}$ & $1.04^{\mathrm{b}}$ & $0.95^{\mathrm{ab}}$ \\
\hline & $30+30$ & $0.95^{\mathrm{ab}}$ & $1.39^{\text {cde }}$ & 1.49 def & $1.38^{\text {cde }}$ & $1.45^{\mathrm{cdef}}$ & $0.95^{\mathrm{ab}}$ & $0.95^{\mathrm{ab}}$ \\
\hline \multirow[t]{2}{*}{ Ears } & 0 & $2.20^{\mathrm{m}}$ & $2.68^{\mathrm{p}}$ & $2.57^{\text {nop }}$ & $2.32^{\mathrm{mn}}$ & $2.59^{\text {op }}$ & $2.37^{\mathrm{mno}}$ & $2.30^{\mathrm{m}}$ \\
\hline & $30+30$ & $2.21^{\mathrm{m}}$ & $2.40^{\mathrm{mno}}$ & $2.47^{\text {mnop }}$ & $2.36^{\mathrm{mno}}$ & $2.45^{\text {mnop }}$ & $2.20^{\mathrm{m}}$ & $2.23^{\mathrm{m}}$ \\
\hline \multicolumn{9}{|l|}{ August 18} \\
\hline \multirow[t]{2}{*}{ Straw } & 0 & $0.38^{\mathrm{a}}$ & $0.54^{\mathrm{cd}}$ & $0.67 \mathrm{ef}^{\mathrm{f}}$ & $0.50^{\text {bed }}$ & $0.71^{f}$ & $0.43^{\mathrm{abc}}$ & $0.43^{a b c}$ \\
\hline & $30+30$ & $0.35^{\mathrm{a}}$ & 0.59 de & 0.59 de & $0.52^{\text {cd }}$ & $0.58^{\mathrm{de}}$ & $0.36^{\mathrm{a}}$ & $0.36^{\mathrm{a}}$ \\
\hline \multirow[t]{2}{*}{ Ears } & 0 & $1.78^{\mathrm{m}}$ & $2.55^{\mathrm{qr}}$ & $2.75^{\mathrm{r}}$ & $2.45^{\mathrm{pq}}$ & $2.70^{r}$ & $2.06^{\text {no }}$ & $1.95^{\mathrm{mn}}$ \\
\hline & $30+30$ & $1.80^{\mathrm{m}}$ & $2.29 \mathrm{p}$ & $2.43 \mathrm{pq}$ & $2.25^{\mathrm{op}}$ & $2.32^{p q}$ & $1.75^{\mathrm{m}}$ & $1.83^{\mathrm{m}}$ \\
\hline
\end{tabular}

Means for samples of the same date followed by a common letter do not differ at $\mathrm{P}=0.05$ 
applied. Statistically significant difference also exists in the nitrogen content of the straw between the irrigated and unirrigated plots with placed urea.

At these later stages of development, the positive effect of the placement of ammonium nitrate-limestone and urea is proved by the respective contents of nitrogen in the straw samples from the unirrigated plots. On these plots placement of urea has also significantly increased the nitrogen content of the ears.

According to the nitrogen content of the samples of July and August, ammonium nitrate-limestone and urea have been equally effective. The only exception is found in the nitrogen content of the ears from the surface-dressed, unirrigated plots in July. Ureaform again, has been less effective than the two other fertilizers.

On the basis of the weight of the samples and their nitrogen content, the nitrogen "yields" were calculated. These data are recorded in Table 3 expressed as $\mathrm{N} \mathrm{kg} / \mathrm{ha}$. On June 2, there is not yet any difference between the treatments. At the later sampling dates, a distinct tendency to a marked increase in the uptake of nitrogen because of fertilizer placement is apparent. Since there was a relatively large variation in the dry matter yields of the replicates, these differences are not always statistically significant. The same holds true also with the effect of irrigation. Even in July and August it has tended to increase the amounts of nitrogen taken up by the plants, particularly on the plots treated with ammonium nitrate-limestone and urea. It may be of interest to note that in the samples of June 16, irrigation did not increase the uptake of nitrogen, if the fertilizers were placed. After the second irrigation, however, an increase also in the uptake of the placed fertilizer nitrogen is demonstrable.

Both irrigation and placement tended to improve also the uptake of nitrogen from ureaform treated soil. Yet, only in the samples of June 30, more nitrogen has been accumulated on the irrigated plots from ureaform than from the soil without the additional nitrogen fertilizers. Later there is a similar tendency, but this is not statistically significant

Table 3. $\mathrm{N}$ in plant samples, $\mathrm{kg} / \mathrm{ha}$

\begin{tabular}{|c|c|c|c|c|c|c|c|c|}
\hline \multirow[t]{2}{*}{ Date } & \multirow{2}{*}{$\begin{array}{l}\text { Irrigation } \\
\text { mm }\end{array}$} & \multirow[t]{2}{*}{ Without N } & \multicolumn{2}{|c|}{$\begin{array}{c}\text { Ammonium nitrate- } \\
\text { limestone }\end{array}$} & \multicolumn{2}{|c|}{ Urea } & \multicolumn{2}{|c|}{ Ureaform } \\
\hline & & & surface & placement & surface & placement & surface & placement \\
\hline June 2 & 0 & $7^{\mathrm{a}}$ & $8^{\mathrm{a}}$ & $9^{\mathrm{a}}$ & $8^{a}$ & $8^{a}$ & $7^{\mathrm{a}}$ & $8^{a}$ \\
\hline June 16 & $\begin{array}{l}0 \\
30\end{array}$ & $\begin{array}{l}22^{\mathrm{a}} \\
26^{\mathrm{a}}\end{array}$ & $\begin{array}{l}30^{\mathrm{ab}} \\
39^{\mathrm{cd}}\end{array}$ & $\begin{array}{l}43^{\mathrm{d}} \\
45^{\mathrm{d}}\end{array}$ & $\begin{array}{l}28^{\mathrm{ab}} \\
35^{\mathrm{bc}}\end{array}$ & $\begin{array}{l}40^{\mathrm{cd}} \\
43^{\mathrm{d}}\end{array}$ & $\begin{array}{l}23^{\mathrm{a}} \\
27^{\mathrm{ab}}\end{array}$ & $\begin{array}{l}25^{\mathrm{a}} \\
29^{\mathrm{ab}}\end{array}$ \\
\hline June 30 & $\begin{array}{c}0 \\
30+30\end{array}$ & $\begin{array}{l}39^{\mathrm{a}} \\
44^{\mathrm{a}}\end{array}$ & $\begin{array}{l}52^{\mathrm{abc}} \\
89^{\mathrm{ef}}\end{array}$ & $\begin{array}{l}69^{\text {cde }} \\
103^{f}\end{array}$ & $\begin{array}{l}56^{\mathrm{abc}} \\
81^{\mathrm{de}}\end{array}$ & $\begin{array}{l}66^{\mathrm{cd}} \\
104^{f}\end{array}$ & $\begin{array}{l}39^{\mathrm{a}} \\
63^{\mathrm{bc}}\end{array}$ & $\begin{array}{l}48^{\mathrm{ab}} \\
70^{\text {cde }}\end{array}$ \\
\hline July 21 & $\begin{array}{c}0 \\
30+30\end{array}$ & $\begin{array}{l}55^{\mathrm{a}} \\
67^{\mathrm{a}}\end{array}$ & $\begin{array}{l}89^{\mathrm{bcd}} \\
119^{\mathrm{ef}}\end{array}$ & $\begin{array}{l}101^{\text {de }} \\
128^{\text {fg }}\end{array}$ & $\begin{array}{l}89^{\mathrm{bcd}} \\
119^{\mathrm{ef}}\end{array}$ & $\begin{array}{l}93^{\mathrm{cd}} \\
140^{\mathrm{g}}\end{array}$ & $\begin{array}{l}68^{\mathrm{ab}} \\
73^{\mathrm{abc}}\end{array}$ & $\begin{array}{l}68^{\mathrm{ab}} \\
74^{\mathrm{abc}}\end{array}$ \\
\hline August 18 & $\begin{array}{c}0 \\
30+30\end{array}$ & $\begin{array}{l}59^{\mathrm{a}} \\
84^{\mathrm{abc}}\end{array}$ & $\begin{array}{l}110^{\mathrm{bcd}} \\
161^{\mathrm{ef}}\end{array}$ & $\begin{array}{l}135^{\mathrm{de}} \\
180^{f}\end{array}$ & $\begin{array}{l}95^{\text {abcd }} \\
140^{\text {def }}\end{array}$ & $\begin{array}{l}126^{\text {cde }} \\
168^{\text {ef }}\end{array}$ & $\begin{array}{l}77^{\mathrm{ab}} \\
76^{\mathrm{ab}}\end{array}$ & $\begin{array}{l}79^{\mathrm{ab}} \\
98^{\mathrm{abcd}}\end{array}$ \\
\hline
\end{tabular}

Means for samples of the same date followed by a common letter do not differ at $\mathrm{P}=0.05$ 
Ureaform is a poorer source of nitrogen for spring wheat than the two other fertilizers which, on the basis of the present data, are equally effective in providing nitrogen under the conditions of this field experiment.

Since the trial was harvested with a combine machine, only results of grain yield are available. Data in Table 4 show that irrigation significantly increased the dry matter yield of winnowed grains, but at the same time decreased their nitrogen content. Yet, the total amount of nitrogen harvested in grains from the plots treated with ammonium nitrate limestone or urea is distinctly increased by irrigation. Placement of these two fertilizers improved the uptake of nitrogen only from unirrigated plots. No difference may be found between the effect of ammonium nitrate limestone and urea in the dry matter yield of grain, in their nitrogen content, or in the amount of nitrogen harvested in grains. Ureaform did not give any significant response, except a slight increase in the "nitrogen yield", when the fertilizer was placed and the soil was irrigated.

Table 4. Grain yield

\begin{tabular}{|c|c|c|c|c|c|c|c|}
\hline \multirow[b]{2}{*}{ Irrigation mm } & & \multicolumn{2}{|c|}{$\begin{array}{l}\text { Dry matter } \\
\mathrm{kg} / \mathrm{ha}\end{array}$} & \multicolumn{2}{|c|}{$\begin{array}{c}\mathrm{N} \% \\
\text { in dry matter }\end{array}$} & \multicolumn{2}{|c|}{$\begin{array}{c}\mathrm{N} \text { in grains } \\
\mathrm{kg} / \mathrm{ha}\end{array}$} \\
\hline & & 0 & $30+30$ & 0 & $30+30$ & 0 & $30+30$ \\
\hline Without N & & $1920^{\mathrm{a}}$ & $2510^{\mathrm{bc}}$ & $2.30^{\mathrm{bc}}$ & $2.13^{\mathrm{ab}}$ & $44^{\mathrm{a}}$ & $53^{\mathrm{a}}$ \\
\hline \multirow[t]{2}{*}{ Ammonium nitrate-limestone } & surface & $2640^{\text {bcd }}$ & $4210^{e}$ & $3.11^{\mathrm{f}}$ & $2.55^{\mathrm{de}}$ & $82^{\mathrm{c}}$ & $107^{e}$ \\
\hline & placement & $3070^{\mathrm{d}}$ & $4550^{e}$ & $3.07^{f}$ & $2.57 \mathrm{de}$ & $94^{\mathrm{d}}$ & $117^{e}$ \\
\hline \multirow[t]{2}{*}{ Urea } & surface & $2740^{\text {cd }}$ & $4150^{e}$ & $2.94^{\mathrm{f}}$ & $2.64^{\mathrm{e}}$ & $81^{\mathrm{c}}$ & $110^{\mathrm{e}}$ \\
\hline & placement & $3050^{\mathrm{d}}$ & $4410^{e}$ & $3.12^{\mathrm{f}}$ & $2.65^{e}$ & $95^{\mathrm{b}}$ & $117^{e}$ \\
\hline \multirow[t]{2}{*}{ Ureaform } & surface & $1990^{\mathrm{a}}$ & $2560^{\mathrm{bc}}$ & $2.42^{\mathrm{cb}}$ & $2.06^{\mathrm{a}}$ & $48^{\mathrm{ab}}$ & $53^{\mathrm{ab}}$ \\
\hline & placement & $2170^{\mathrm{ab}}$ & $2840^{\text {cd }}$ & $2.40^{\mathrm{cd}}$ & $2.10^{\mathrm{a}}$ & $52^{\mathrm{ab}}$ & $60^{\mathrm{b}}$ \\
\hline
\end{tabular}

Means in the two corresponding columns $n 0 m$ and $n 30+30 n$ followed by a common letter do not differ at $\mathbf{P}=\mathbf{0 . 0 5}$

\section{Discussion}

The results of the present study indicate that, under these conditions, both irrigation and, apparently to a smaller extent, placement of nitrogen fertilizers distinctly improved the uptake of nitrogen by spring wheat. It may be calculated, on the basis of data in Table 4, that placement of ammonium nitrate limestone or urea did increase the amount of nitrogen in the grain yields, on the average, by $13 \mathrm{~kg} / \mathrm{ha}$ without irrigation, but not significantly when irrigated. The irrigation, on the other hand, increased the nitrogen content of grain yields, averagely, by $27 \mathrm{~kg} / \mathrm{ha}$ when the fertilizers were applied on the surface, and by $23 \mathrm{~kg} / \mathrm{ha}$ when the fertilizers were placed. Thus, the higher dry matter yield produced by irrigation more than compensated the typical decrease in the percentage of nitrogen in the grains. 
The additional nitrogen applied as ammonium nitrate limestone or as urea corresponded to $120 \mathrm{~kg} \mathrm{~N} / \mathrm{ha}$. Its apparent recovery in the grain yields, calculated as the mean difference between the nitrogen yields of the respective treatments and that without additional nitrogen, is the following:

$\begin{array}{lll}\text { without irrigation, surface dressing } & 31 \% \\ & \text { placement } & 42 \% \\ \text { irrigated, } & \text { surface dressing } & 54 \% \\ & \text { placement } & 61 \%\end{array}$

Thus, fertilizer placement with irrigation almost doubled the apparent recovery of fertilizer nitrogen in the grain yield of spring wheat.

Unfortunately, straw yields were not available, but the plant samples collected on August 18, only two days before harvest, may give an approximate basis for an estimation of the apparent recovery of fertilizer nitrogen in the total yield. The rather large variation due to the small sampling area, decreases, of course, the accuracy and the reliability of these estimations. The apparent recovery is, on average, the following:

$\begin{array}{ccc}\text { without irrigation, surface dressing } & 36 \% \\ & \text { placement } & 60 \% \\ \text { irrigated } & \text { surface dressing } 76 \% \\ & \text { placement } & 96 \%\end{array}$

These percentages are fairly well in accordance with the results obtained on the basis of the grain yields, provided that there is in grains about twice as much nitrogen as in the straw yield.

It is likely that the higher uptake of nitrogen from the irrigated soil is to some extent due to a more rapid mineralization of soil nitrogen. On the other hand, the larger root system of the irrigated plants (KÄHÄRI and ELONEN 1969) probably contains a larger amount of fertilizer nitrogen than does the smaller root mass in the unirrigated plots. Thus the apparent recovery of fertilizer nitrogen estimated on the basis of the aerial parts of wheat may be slightly lower than the real uptake of fertilizer nitrogen by the whole plants. This may be applicable also to the effects of the fertilizer placement.

In any case, it is beyond dispute that in this field trial placement of urea or ammonium nitrate limestone, and irrigation in June twice with $30 \mathrm{~mm}$ water, resulted in an almost quantitative apparent recovery of the $120 \mathrm{~kg}$ of nitrogen applied per hectare.

It is noteworthy that though irrigation decreased the nitrogen content of the dry matter in the later stages of development, it did markedly increase the nitrogen content of the wheat plants in June, in the period which in Finland is likely to be particularly important in the development of spring cereals. Analyses for other nutrients also proved the beneficial effect of irrigation on the contents of phosphorus, potassium, magnesium, and calcium in the wheat plants in the middle and at the end of June. The higher uptake of nitrogen due to the fertilizer placement, also to some extent, increased the content of potassium, calcium, and magnesium in the plants which were not irrigated. A good supply of these essential elements in the plants during the critical period apparently offered favourable conditions for a higher production. 


\section{$S$ u $m$ m a ry}

The effect of irrigation and fertilizer placement on the accumulation of nitrogen in the aerial parts of spring wheat was studied in the relatively dry summer 1969, on the basis of plant samples collected at various stages of development from a field trial on silty clay soil. In addition to $16 \mathrm{~kg} / \mathrm{ha}$ of nitrogen in the basal dressing, $120 \mathrm{~kg} / \mathrm{ha}$ of nitrogen was applied as ammonium nitrate limestone, as urea, or as Ureaform, either on the surface, or in rows at the depth of $8 \mathrm{~cm}$. $60 \mathrm{~mm}$ of water was applied by sprinkler irrigation, one half about three, and the other half about four weeks after sprouting.

Under the conditions of this trial, spring wheat only slightly responded to Ureaform. No significant difference in the effect of urea and ammonium nitrate limestone could be detected. Placement of these two fertilizers tended to increase both the amount of dry matter and its content of nitrogen; these effects were more significant without irrigation. Though irrigation, usually, markedly increased the total amount of nitrogen in the aerial parts of the plants, this was in the later stages of development due only to higher yields of dry matter, since in July the positive effect of irrigation on the percentage of nitrogen in plant dry matter changed to a negative effect.

In the grain yields the apparent recovery of nitrogen in urea or ammonium nitrate limestone was estimated to be only about 30 per cent of the $120 \mathrm{~kg} \mathrm{~N} / \mathrm{ha}$ applied as surface dressing. Irrigation increased this recovery to 54 per cent, placement of the fertilizer to 42 per cent, and both placement and irrigation resulted in an apparent recovery of 61 per cent.

On the basis of plant samples collected two days before harvest, the apparent recovery of nitrogen in urea or ammonium nitrate limestone by the aerial parts of wheat was estimated to be, on the average, 36 per cent from the surface-dressing, and 60 per cent when the fertilizers were placed. Irrigation increased the apparent recovery in the first case to 76 per cent and in the latter case to 96 per cent.

Thus, in the field experiment the uptake of fertilizer nitrogen by spring wheat was markedly increased by irrigation and to a lesser extent by fertilizer placement. Both treatments together are recommended.

\section{REFERENCES}

Cooke, G. W. 1964. Nitrogen fertilisers. Proc. Fertil. Soc. No 80.

Duncan, D. B. 1955. Multiple range and multiple $F$ tests. Biometrics 11: $1-42$.

Elonen, P. \& Nieminen, L. \& KarA, O. 1967. Sprinkler irrigation on clay soils in southern Finland II. J. Sci. Agr. Soc. Finland 39: 78-89.

KAILA, A. 1965. Apparent recovery of fertilizer nitrogen. Ibid. 37: 163-174.

-»- \& Hänninen, P. 1961. Fertilizer nitrogen in soil. Ibid. 33: 169-184.

KÄHÄRI, J. \& ELONEN, P. 1969. Effect of placement of fertilizer and sprinkler irrigation on the development of spring cereals on the basis of root investigations. Ibid. 41: 89-104.

Russell, E. W. 1961. Soil conditions and plant growth. London, 688 p. 


\title{
SELOSTUS \\ SADETUKSEN JA TYPPILANNOITTEIDEN SIJOITUKSEN VAIKUTUS LANNOITETYPEN HYVÄKSIKÄYTTÖÖN
}

\author{
Armi Kaila ja Paavo Elonen
}

rliopiston maanviljelyskemian laitos, Viikki

Sadetuksen ja typpilannoitteen sijoituksen vaikutusta kevätvehnän typen ottoon tutkittiin keräämällä poikkeuksellisen kuivana kesänä 1969 näytteitä eri kehitysvaiheissa kasvin maanpäällisistä osista Pakankylässä Maatalouskoneiden tutkimuslaitoksen kanssa suoritetusta kenttäkokeesta. Peruslannoituksena annetussa ammonoidussa PK-lannoksessa tuli maahan $16 \mathrm{~kg} \mathrm{~N} / \mathrm{ha}$. Sen lisäksi annettiin $120 \mathrm{~kg} \mathrm{~N} / \mathrm{ha}$ Oulunsalpietarina, ureana tai Ureaform-valmisteena joko pintaan tai sijoitettuna riveihin 8 sm syvyyteen. $30 \mathrm{~mm}: \mathrm{n}$ sadetus suoritettiin sekä 9.6. etta 17.6.

Ureaformilla ei ollut juuri lainkaan vaikutusta tässä kenttäkokeessa. Urea ja Oulunsalpietari osoittautuivat yhtä tehokkaiksi. Niiden sijoittaminen näytti lisäävän sekä kasvin kuiva-aineen määrää että sen typenpitoisuutta, etenkin sadettamattomilla ruuduilla. Sadetus ḷ̣säsi tavallisesti merkitsevästi mtyppisatoa", mutta heinä- ja elokuussa tämä johtui vain kuiva-aineen määrän lisääntymisestä: heinäkuusta alkaen sadetuksen vaikutus rupesi ilmenemään tyypillisenä kasvin typenpitoisuuden alenemisena vastaavaan sadettamattomaan verrattuna.

Jyväsatojen perusteella arvioitiin typpilannoitteiden näennäinen hyväksikäyttö, lannoitettujen ja 0-ruutujen "typpisatojen" erotuksen perusteella laskettuna, vain noin $30 \%: \mathrm{ksi}$ pintalannoituksena annetusta (120 kg N/ha). Sijoitus lisäsi hyväksikäytön $42 \%: \mathrm{ksi}$, sadetus $52 \%: \mathrm{ksi}$ ja molemmat toimenpiteet $61 \%$ :ksi.

Kahta päivää ennen sadonkorjuuta kerättyjen kasvinäytteiden analyysien perusteella arvioitiin koko sadon ottaneen Oulunsalpietarista ja ureasta keskimäärin $36 \%$ pintalannoituksena annetusta ja 60 prosenttia sijoitetusta. Sadetus paransi hyväksikäyttöä edellisessä tapauksessa $76 \%$ :iin, jälkimmäisessä $96 \%$ :iin.

Todettiin, että sadetus oli kuivana kasvukautena tehostanut merkittävästi helposti liukenevien typpilannoitteiden hyväksikäyttöä, sijoitus vähemmän. Molemmat yhdessä antavat parhaan tuloksen. 